\title{
Hoe rechters denken
}

\author{
Maarten van Wel
}

\section{Inleiding}

De titel van deze bijdrage is een vertaling van How Judges Think, een recent boek van de Amerikaanse rechtstheoreticus en rechter Richard Posner (Posner 2008). Deze titel intrigeert mij, omdat beantwoording van de vraag die daarin besloten ligt zo veel belooft.

Eenieder die direct of indirect te maken heeft met rechterlijke oordeelsvorming heeft er namelijk belang bij om te weten hoe rechters denken. In de eerste plaats natuurlijk de rechter zelf. Moderne instrumenten, zoals intervisie en cursussen zelfreflectie, kunnen per slot van rekening worden teruggevoerd op de klassieke opdracht 'ken uzelf. Maar ook de burger, onderworpen aan een (toekomstig) rechterlijk oordeel, zal er zijn handelen of proceshouding op kunnen aanpassen. De advocaat zal er zijn cliënten over kunnen adviseren of zijn processtrategie op kunnen afstemmen. De officier van justitie zal er de tenlastelegging of het procesdossier mee op één lijn kunnen brengen. De wetgever zal wetten kunnen maken waarmee een rechter uit de voeten kan. En ten slotte kan ook de rechtswetenschapper ${ }^{1}$ baat hebben bij inzicht in de rechterlijke denkwijze. Daarbij hoeft men niet zo ver te gaan om het recht te definiëren als het louter voorspellen van rechterlijke oordelen. ${ }^{2}$ In elke theorie waarin vraagstukken van rechtsvinding of -vorming als verschijningsvormen van rechterlijke interpretatie aan de orde komen, zal een analyse van rechterlijke oordeelsvorming ontegenzeglijk een belangrijke rol spelen. Maar zelfs theorieën die deze vraagstukken onbehandeld laten, zullen soms verstrikt raken in het web van de toepassing van algemene regels in de concrete rechtspraktijk. En de rechter fungeert nu eenmaal als spin in dat web. Het rechterlijk oordeel markeert aldus één van die ondeelbare ogenblikken dat theorie en praktijk elkaar ontmoeten.

1 In deze bijdrage gebruik ik het begrip 'rechtswetenschap' als tegenpool van het begrip 'rechtspraktijk'. Onder rechtswetenschap versta ik dan ook elke wetenschappelijke benadering van het recht of onderdelen daarvan. Ik ben mij ervan bewust dat deze kwalificatie mogelijk niet volledig overeenstemt met de gangbare kwalificatie van dit begrip en dat hierop dus ongetwijfeld genoeg valt af te dingen. Omwille van de overzichtelijkheid van deze bijdrage zal ik toch dit vereenvoudigde schema hanteren.

2 Vergelijk bijvoorbeeld het citaat van de Amerikaanse rechtspositivist en rechter Oliver Wendell Holmes Jr. (1897): 'Take the fundamental question, What constitutes the law? You will find some text writers telling you that it is something different from what is decided by the courts of Massachusetts or England, that it is a system of reason, that it is a deduction from principles of ethics or admitted axioms or what not, which may or may not coincide with the decisions. But if we take the view of our friend the bad man we shall find that he does not care two straws for the axioms or deductions, but that he does want to know what the Massachusetts or English courts are likely to do in fact. I am much of this mind. The prophecies of what the courts will do in fact, and nothing more pretentious, are what I mean by the law.' 


\section{Drie manieren van beantwoording}

De vraag 'hoe denken rechters?' is niet alleen intrigerend omdat de beantwoording daarvan veelbelovend is voor veel - zo niet alle - bij de rechtspraktijk betrokken belanghebbenden. Het is bovendien een vraag die meerdere soorten antwoorden mogelijk maakt; op zijn minst evenzoveel soorten antwoorden als er manieren zijn om de vraag te begrijpen. Ik noem er drie.

De vraag kan worden opgevat als het startpunt van een zoektocht naar de overtuigingen, beweegredenen en vooroordelen van de rechter. Met andere woorden, een zoektocht naar de mens achter rechterlijke oordeelsvorming. In zijn boek lijkt het alsof Posner de vraag op deze manier heeft willen stellen. In ieder geval beantwoordt hij hem grotendeels op deze manier. De vraag kan echter ook worden opgevat als het startpunt van een meer technische analyse van het rechterlijk oordeel. Met andere woorden, een analyse van de methode van rechterlijke oordeelsvorming. Dit is een manier van de vraag stellen die het meest lijkt te beantwoorden aan de opzet van dit tijdschrift. Niet ten onrechte wordt in het eerste redactioneel namelijk opgemerkt dat voor sommigen de vraag naar een rechtswetenschappelijke methode niet los is te zien van methoden van rechtsvinding (Taekema \& Van Klink 2011, p. 4). In dat licht is het ook niet verwonderlijk dat de eerste aflevering van dit tijdschrift onder meer een boekbespreking bevat van het boek Thinking Like a Lawyer: A New Introduction to Legal Reasoning van Frederick Schauer (Rozemond 2011). Ten slotte kan de vraag worden opgevat als het startpunt van een beschrijving van de omgeving waarbinnen het rechterlijk oordeel wordt gevormd. Met andere woorden, een beschrijving van de context van rechterlijke oordeelsvorming. Als de vraag op deze manier wordt gesteld, dan moet een beoordelingspraktijk worden beoordeeld. Naar goed rechterlijk gebruik dienen hierbij alle ter zake dienende omstandigheden van het geval te worden betrokken.

In deze bijdrage zal ik de vraag 'hoe denken rechters?' alleen op de derde manier beantwoorden. De reden hiervoor is dat de eerste twee manieren zich al verzekerd weten van voldoende rechtswetenschappelijke aandacht. Voor mijn gevoel is er echter ten onrechte minder aandacht voor de context van rechterlijke oordeelsvorming. Deels zal de relatieve geslotenheid van de rechterlijke organisatie hier debet aan zijn. Bovendien heeft de redactie mij gevraagd vooral mijn eigen praktijkervaringen nader te belichten. Ik stel me zo voor dat een beschrijving door een ervaringsdeskundige van de situationele invloeden op rechterlijke oordeelsvorming een aanvulling kan vormen op rechtswetenschappelijke studies naar rechterlijke oordeelsvorming. Hierbij wil ik meteen aantekenen dat ik geen (zuiver) wetenschappelijke bijdrage heb kunnen en willen schrijven. In dit licht dank ik de redactie voor het plaatsen van deze zelfreflectieve bijdrage.

\subsection{Perspectief van beantwoording}

Ik zal mijn beantwoording plaatsen in het perspectief van de rechter in opleiding. De keuze voor dit perspectief heeft meerdere voordelen. Allereerst kan ik - tijdens het schrijven van deze bijdrage zelf rechterlijk ambtenaar in opleiding - op 
deze manier putten uit mijn eigen ervaringen. ${ }^{3}$ Daarnaast is een rechter in opleiding zich nog volop bewust van de eigenaardigheden van het ambt, in de geheimen waarvan hij stap voor stap wordt ingewijd, terwijl hij tegelijkertijd nog niet zodanig is geconditioneerd dat hij al vervreemd is geraakt van de denkwijze van de buitenwereld. ${ }^{4}$ Ten slotte heeft dit perspectief als voordeel dat noodzakelijkerwijs zal worden gerefereerd aan rechterlijke oordeelsvorming in eerste aanleg. De rechtbank is namelijk de plek waar verreweg de meeste rechters in opleiding worden opgeleid. Het is bovendien de plek waar het leeuwendeel van de rechterlijke oordelen wordt gevormd. De commentatoren van de rechtspraak lijken echter niet graag af te dalen naar de eerste lijn waar - aan de lopende band van het recht - rechters met hun laarzen in de modder van de maatschappij vonnis na vonnis produceren, zoals een rechter uit de Selectiecommissie rechterlijke macht het tijdens mijn sollicitatie beeldend uitdrukte. Liever ontraadselen zij de arresten van 's lands hoogste rechtscollege. Ten burele van de Hoge Raad der Nederlanden, waar zelden zittingen worden gehouden, weerklinkt echter slechts een vage echo van de rechterlijke ambachtelijkheid uit de verre arrondissementen. Het is dan ook maar zeer de vraag of een beantwoording van de vraag 'hoe denken rechters?' zich zou moeten beperken tot een onderzoek naar de denkwijze van de cassatierechter. Iets wat Posner overigens wel lijkt te doen, aangezien hij zijn analyse van rechterlijk gedrag vooral toetst aan de rechters van het Amerikaanse Supreme Court.

Voordat ik mijn beantwoording van de vraag daadwerkelijk zal aanvangen, wil ik eerst nog benadrukken dat ik deze bijdrage op persoonlijke titel schrijf. Dat wil zeggen dat mijn bespiegelingen niet noodzakelijkerwijs de zienswijze weergeven van de rechterlijke macht in het algemeen, dan wel van het opleidingsinstituut daarvan of mijn opleidingsgenoten in het bijzonder. Voor officiële missies en visies verwijs ik de geïnteresseerde lezer naar de websites van de Raad voor de Rechtspraak (<www.rechtspraak.nl $\rangle$ ) en van de Stichting Studiecentrum Rechtspleging (<www.ssr.nl $>)$.

\section{Een opleiding op niveaus}

Voor een rechter in opleiding bestaat de context van rechterlijke oordeelsvorming uit de omgeving waarbinnen hem wordt geleerd een rechterlijk oordeel te vormen. Voor beantwoording van de vraag hoe een rechter in opleiding leert een rechterlijk oordeel te vormen, is het allereerst van belang iets te weten over deze

3 Waar ik schrijf over de opleiding tot rechter, beschrijf ik het door mij gevolgde raio-traject. De inhoud en vorm van dit traject zijn op dit moment aan grote veranderingen onderhevig. Bovendien bestaan er naast het raio-traject andere rechterlijke opleidingstrajecten, die in deze bijdrage nog kort zullen worden belicht.

$4 \quad$ Ik gebruik in deze bijdrage voor het woord rechter (in opleiding) mannelijke verwijzende voornaamwoorden, omdat dit woord zelf mannelijk is. Dit doet overigens geen recht aan de manvrouwverhouding binnen de rechterlijke macht als geheel en nog minder aan deze verhouding binnen de raio-opleiding. 
opleiding zelf. Er zijn in de eerstelijnsrechtspraak op dit moment drie manieren om rechter te worden.

\subsection{Drie manieren om rechter te worden}

In de eerste plaats worden sommige rechters gevraagd of solliciteren zij voor een functie als rechter-plaatsvervanger. Dit zijn veelal juristen met een specifieke expertise binnen de rechtspraktijk en/of rechtswetenschap. Zij zijn geen beroepsrechters, maar zeker ook geen lekenrechters. Voor zover ik weet, krijgen zij geen noemenswaardige opleiding in rechterlijke oordeelsvorming. Van hen wordt blijkbaar verwacht dat zij dit al kunnen of dat zij dit zich eenmaal gehuld in rechterstoga vanzelf eigen zullen maken. Doordat rechter-plaatsvervangers, zeker in het begin van hun aanstelling, veelal plaatsnemen in een meervoudige kamer, kan dit eventuele gemis waar nodig worden gecompenseerd door de overige leden van het rechterlijk college.

Daarnaast kunnen juristen met minimaal zes jaar relevante werkervaring solliciteren voor een opleidingsplek in een eenjarig rio-traject. Binnen dit traject krijgt een rechter in opleiding in twee sectoren van de rechtbank telkens in zes maanden een stoomcursus rechterschap te verwerken. Het is mij niet bekend in hoeverre er binnen dit traject specifiek aandacht wordt besteed aan rechterlijke oordeelsvorming. Ik vermoed dat dit in grote lijnen overeenkomt met de aandacht hiervoor in het hierna te bespreken raio-traject, met dien verstande dat in het rio-traject alle kennis en vaardigheden in een zeer beperkt tijdsbestek moeten worden aangeleerd, en dat er van meet af aan een bijna volledige zelfstandigheid wordt vereist.

Ten slotte is er een vier- tot zesjarig raio-traject. Binnen dit traject vervult een rechter in opleiding zes maanden de rol van griffier in de strafsector, tien maanden de rol van rechter in de civiele sector, tien maanden de rol van rechter in de bestuurssector en twaalf maanden de rol van officier van justitie. Na deze basisstages moet een keuze worden gemaakt voor het ambt van rechter of officier van justitie, waarna een verdiepingsstage volgt van tien maanden bij een van de sectoren van de rechtbank naar keuze respectievelijk het parket. Afhankelijk van de relevantie van zijn voorervaring volgt de rechter in opleiding na deze vierjarige binnenstage nog een buitenstage van maximaal twee jaar, waarvan minimaal anderhalf jaar in de Nederlandse advocatuur.

Omwille van de overzichtelijkheid en mijn eigen referentiekader beperk ik mij in het vervolg van deze bijdrage tot het aanleren van rechterlijke oordeelsvorming binnen het raio-traject op de rechtbank. Het grootste gedeelte van de tijd wordt een rechter in opleiding opgeleid op de rechtbank waar hij is geplaatst. Daarnaast neemt hij deel aan een groot aantal cursussen, dat wordt aangeboden door het opleidingsinstituut van de rechterlijke macht. Hoewel de frequentie van cursussen met het voortschrijden van de opleiding afneemt, vindt een niet onaanzienlijk deel van deze opleiding dus plaats op cursuslocaties. Ik heb het niet nagerekend, maar in oudere publicaties wordt een cursusbelasting van bijna 50 dagen in de basisstages (totaal 38 maanden) genoemd (Köhne-Hoegen 2006, p. 187). De cursussen worden bijna zonder uitzondering gegeven door zeer ervaren en gekwalificeerde docenten uit de rechtspraktijk en/of rechtswetenschap. 


\subsection{Opleiding op locatie}

De aangeboden cursussen kunnen worden onderverdeeld in drie categorieën. Bij de eerste categorie cursussen ligt de nadruk op juridisch-inhoudelijke kennisoverdracht. Hoewel er terecht van wordt uitgegaan dat deze kennis in de basis al aanwezig is, geven dergelijke cursussen een noodzakelijke verdieping op detailniveau in vooral procesrechtelijke onderwerpen. Deze onderwerpen zijn aan de orde van de dag in de praktijk, maar lijken op universiteiten onvoldoende aandacht te krijgen. Overigens bieden sommige rechtbanken, in aanvulling op dit soort cursussen, zelf bijeenkomsten aan voor rechters in opleiding, waarin veelvoorkomende onderwerpen door opleidingsgenoten worden besproken.

De tweede categorie cursussen is gericht op het aanleren van vaardigheden. Onder begeleiding van docenten met verschillende achtergronden en soms met behulp van acteurs worden praktijksituaties nagebootst, waarna aan de hand van video-opnamen en observaties van opleidingsgenoten feedback wordt gegeven op onderdelen van het optreden, zoals presentatie, bejegening en omgang met emoties. Ook met betrekking tot dit soort cursussen bieden sommige rechtbanken aanvullende oefenmogelijkheden aan, waarbij onder begeleiding van ervaren rechters verder kan worden proefgedraaid met zittingen en getuigenverhoren.

De derde categorie cursussen heeft betrekking op reflectie op het rechterlijk werk. Hierbij kan men denken aan cursussen ethiek, morele dilemma's en zelfreflectie. Bovendien wordt in de laatste fase van de opleiding een waaier aan keuzecursussen aangeboden, waaronder beschouwende cursussen zoals de cursus recht $\&$ literatuur.

Al deze cursussen zijn nodig voor het aanleren van deugdelijke rechterlijke oordeelsvorming. Een rechter moet weten welke bouwstenen mogelijk relevant of zelfs onmisbaar zijn voor zijn oordeel, en op welke onderdelen hij al dan niet ambtshalve moet doorvragen. Bovendien moet een rechter de procedureregels kennen, aangezien hij deze regels zelf in acht moet nemen en moet bewaken. Het op deze manier kunnen overzien van de procedure is iets wat wordt aangeleerd tijdens de eerste categorie cursussen.

Daarnaast moet een rechter beschikken over de vaardigheden om bovenbedoelde informatie te destilleren uit soms omvangrijke en ingewikkelde processtukken, mondelinge toelichtingen daarop en rechtsbronnen. Hij moet vervolgens in staat zijn om zijn beslissingen op zodanige wijze te articuleren dat ze niet alleen juridisch verdedigbaar zijn, maar dat partijen ook het gevoel krijgen dat zij zijn gehoord. Dat een rechter de procesorde moet bewaken betekent niet alleen dat hij partijen rechtvaardig moet behandelen, maar ook dat hij in staat moet zijn met een zekere dwingendheid en voortvarendheid tijdens de procedure effectief en efficiënt te handelen. Het op deze manier kunnen nemen van beslissingen is iets wat wordt aangeleerd tijdens de tweede categorie cursussen.

Ten slotte moet een rechter beschikken over een stevige en integere persoonlijkheid. Van hem wordt gevraagd volstrekt onafhankelijk en onpartijdig te zijn. Soms moeten knopen worden doorgehakt in zaken met veel emotionele of politieke lading. Daarbij moet hij bereid zijn af te wijken van heersende opvattingen in de samenleving of van hogere rechters. Bovendien heeft een rechter niet de luxe om een beslissing eindeloos voor zich uit te schuiven of te verzanden in een 
enerzijds-anderzijdsbetoog. Al deze eisen van het ambt hebben soms verstrekkende gevolgen voor de gemoedstoestand of het privéleven van een rechter. Het kunnen omgaan met deze rol en druk is iets wat wordt aangeleerd tijdens de derde categorie cursussen.

\subsection{Opleiding op de werkvloer}

Deze cursussen zijn alle gericht op toepassing in de praktijk. Bovendien vindt op de werkvloer, in ieder geval in tijd gemeten, het overgrote gedeelte van de opleiding plaats. Bovendien worden de kennis en vaardigheden, die zijn aangeleerd tijdens de cursussen, op de werkvloer verder aangevuld en verdiept. Het is daarom minstens even belangrijk om zicht te krijgen op de opleiding tot rechter in de praktijk.

De opleiding tot rechter in de praktijk is sterk zaaksafhankelijk en mist daardoor de structurele benadering van de cursussen. Tijdens een zaak over Europees insolventierecht zal een rechter in opleiding zich bijvoorbeeld in korte tijd moeten verdiepen in alle internationaal en nationaal privaatrechtelijke voetangels en klemmen op dit vlak. Iets vergelijkbaars geldt voor een vreemdelingenzaak, waarin de Rwandese genocide van 1994 een belangrijke rol speelt, of een strafzaak over de diefstal van virtuele goederen in het internetspel RuneScape. De meerwaarde van deze specifieke leerschool in de praktijk is dat de rechter in opleiding leert dat elke zaak in potentie oneindig veel complexer en weerbarstiger is dan welke noodzakelijkerwijs gesimplificeerde oefencasus dan ook. Naast inhoudelijke problemen dienen zich daarbij ook vaak onverwacht praktische problemen aan. Dit geldt overigens ook voor de oplossingen daarvan, zoals een weigerende printer in de zittingszaal, de parketpolitie die middenin een uitlopende zaak meedeelt dat ze de rechtbank gaat sluiten of een advocaat die belt dat hij muurvast in de file staat. Kortom, law in action in optima forma. Het is als rechter in opleiding, zeker in het begin, flink lastig om het scala aan problemen en oplossingen te kunnen overzien en deze oplossingen zo nodig toe te passen, zonder dat partijen daar onnodige hinder van ondervinden.

\subsection{Opleiding als socialisatieproces}

Het is echter niet alleen vakinhoudelijke groei en kennis van de organisatie die een rechter in opleiding ontwikkelt. Hij wordt daarnaast ook geacht een persoonlijke groei door te maken. Heel tastbaar maakt een rechter in opleiding een ontwikkeling door van het verrichten van voornamelijk ondersteunend werk en het opstellen van concepten in het begin naar het uitoefenen van een zelfstandige functie, waarbij hij de leiding heeft over het onderzoek ter terechtzitting en de afdoening van de zaak, aan het einde. Meer abstract moet de rechter in opleiding komen te beschikken over een zogeheten rechtersattitude. Verschillende auteurs beschrijven dit proces van persoonlijke groei als een socialisatieproces. De rechterlijke macht wordt gebruikmakend van de terminologie van de Amerikaanse rechtsantropologe Sally Moore wel gekenschetst als een semi-autonoom sociaal 
veld. ${ }^{5}$ Andere terugkerende elementen in omschrijvingen van de cultuur van de rechterlijke macht zijn: betrekkelijk homogeen, gematigd, terughoudend, formeel, bureaucratisch, professioneel, functioneel elitair en solidair. In ieder geval is sprake van een relatief kleine groep (ongeveer 2.000 leden), waarbinnen groepseigen gedragsnormen gelden, die de rechter in opleiding zich eigen moet zien te maken. Deze gedragsnormen hebben betrekking op alle onderdelen van de cultuur binnen een (sector of team van een) rechtbank, zoals de hiërarchische verhoudingen, benaderbaarheid en taalgebruik, maar bijvoorbeeld ook lunch- en kledinggewoonten. Een oud-rechter in opleiding heeft dit socialisatieproces geanalyseerd aan de hand van een gangbare theorie over socialisatieprocessen en onderverdeeld in drie fasen. ${ }^{6}$ Haar analyse bevat waardevolle inzichten over dit belangrijke onderdeel van de opleiding, zodat ik die hieronder in samengevatte vorm zal weergeven.

Tijdens de eerste fase van het socialisatieproces is sprake van het min of meer kritiekloos kopiëren van het gedrag van anderen in de groep, omdat de rechter in opleiding daar graag zo snel mogelijk onderdeel van uit wil maken en negatieve reacties probeert te vermijden. In het begin, als griffier bij de strafsector, observeert de rechter in opleiding het gedrag van ervaren secretarissen en vraagt hij hen om voorbeelden van processen-verbaal en vonnissen, die hij vervolgens gebruikt in zijn eigen zaken. Ook bij de volgende sectoren, vooral in de eerste maanden, is de rechter in opleiding vooral bezig om zich zo snel mogelijk de werkwijzen en de schrijf- en denkstijl van de rechter, op wiens naam hij vonnissen schrijft, eigen te maken. De steeds terugkerende beoordelingen, vaak van elk vonnis en elke zitting, kunnen als een behoorlijke druk worden ervaren en hebben een conformerende uitwerking. De grootste zorg van een rechter in opleiding tijdens deze fase is namelijk dat hij negatief wordt beoordeeld op zijn gedrag of productie. Een dergelijke beoordeling kan leiden tot het vroegtijdig moeten verlaten van de opleiding of een magere eindbeoordeling die (ingebeelde) gevolgen kan hebben voor het vervolg.

Tijdens de tweede fase van het socialisatieproces is niet alleen sprake van kopiëren van gedrag, maar ook van het zich identificeren ermee. De rechter in opleiding is niet alleen meer bang voor negatieve reacties bij non-conform gedrag, maar is de gedragsnormen als nastrevenswaardig gaan beschouwen. Het conformeren aan deze normen geeft hem daarom een goed gevoel. Deze fase manifesteert zich wat later in de opleiding en dan vaak in de sector waarmee de rechter in opleiding de meeste affiniteit voelt. In deze fase kan het ook gebeuren dat de rol van de opleider verandert. Tijdens de eerste fase was hij vooral een beoordelaar, die door zijn ervaring en beoordelingsmacht ontzag inboezemde. Tijdens deze fase kan hij een rolmodel worden, omdat de rechter in opleiding graag later op dezelfde manier zou willen functioneren.

5 In Köhne-Hoegen 2006, p. 188, wordt in dit verband verwezen naar: S.F. Moore, 'Law and Social Change: The Semi-Autonomous Social Field as an Appropriate Subject of Study', Law \& Society Review 1973-7, p. 719-746.

6 Ik maak gebruik van de theorie van de Nederlandse (rechts)psycholoog Dick Hessing (KöhneHoegen 2006, p. 188-189). 
Tijdens de derde fase is sprake van daadwerkelijke internalisering van de gedragsnormen. De rechter in opleiding heeft de groepsnormen tot zijn eigen normen gemaakt en gedraagt zich dienovereenkomstig. Er is geen sprake meer van angst voor negatieve reacties of het opkijken tegen (leden van) de groep. De rechter in opleiding is zelf onderdeel geworden van de groep. Deze fase wordt vaak goed zichtbaar tijdens de verdiepingsstage, waarin de rechter in opleiding wordt geacht nagenoeg zelfstandig op te treden. Om dit zonder sturing van een opleider succesvol te doen, moet de rechter in opleiding zich op ongedwongen wijze kunnen presenteren als vertegenwoordiger van de rechterlijke macht.

Bij deze analyse kunnen een hoop kanttekeningen worden geplaatst. Niet alle rechters in opleiding doorlopen deze fasen allemaal of in deze volgorde. Soms zal bijvoorbeeld de laatste fase pas na de opleiding worden bereikt. Bovendien zijn overgangen tussen fasen vaak vloeiend en zal soms sprake zijn van een (tijdelijke) terugval in een vorige fase. Ten slotte kan ter relativering worden opgemerkt dat eigenlijk elke vergelijkbare organisatie een vergelijkbaar socialisatieproces kent.

\subsection{Leren door conditionering}

Ondanks bovengenoemde kanttekeningen blijft deze analyse voor mij persoonlijk zeer herkenbaar. Ik kan in mijn eigen opleiding vrij eenvoudig de overgang in fasen aanwijzen. Bovendien is het noodzakelijk om dit proces te onderkennen op het moment dat je wilt beschrijven hoe rechters in opleiding wordt geleerd een rechterlijk oordeel te vormen. Dit leerproces is voor een groot deel namelijk een vorm van conditionering. De rechter in opleiding moet leren denken als een rechter. Dit begint al bij de eerste bestudering van het dossier, en vervolgens bij elk nieuw stuk of elke nieuwe opmerking ter zitting. Op de werkvloer wordt de rechter in opleiding de mogelijkheid geboden de kunst bij ervaren rechters af te kijken. In deze zin heeft het socialisatieproces een sterk vormende en conformerende werking. In dit verband is het ook goed om de belangrijke rol van de opleider te benadrukken, tot wie de rechter in opleiding in een soort meester-gezelverhouding staat.

Er zitten echter ook negatieve kanten aan een sterk socialisatieproces. De conformerende druk kan voor sommigen te groot blijken. Dit kan ertoe leiden dat dissidente geesten onnodig uittreden, terwijl organisaties tegenspraak nodig hebben om zich aan te passen aan veranderende omstandigheden en om tunnelvisie te voorkomen. ${ }^{7}$ Maar niet alleen een gebrek aan andersdenkenden kan kwalijke gevolgen hebben. Een kritiek op de raio-opleiding, die verband lijkt te houden met het sterke socialisatieproces, is dat deze opleiding slechts identieke, middelmatige en risicomijdende rechters aflevert. In de literatuur treft men omschrijvingen van raio's aan als: grijze muizen, een eenheidsworst, een heel braaf clubje en een groep die volledig de schutkleur aanneemt van de club waarin ze terechtkomen. De eerste voorzitter van de Raad voor de Rechtspraak Bart van Delden verwoordt het als volgt: 'We zijn heel sterk in het uitsnijden van de uitersten. Er zitten weinig domme mensen in de rechterlijke macht. En weinig briljante' (Jensma 2007).

7 De oud-rechter in opleiding Ernestine Köhne-Hoegen heeft onderzocht hoe deze uittreders het socialisatieproces hebben ervaren (Köhne-Hoegen 2008). 
Een knellend socialisatieproces kan bovendien een onnodig beperkende uitwerking hebben op rechterlijke onafhankelijkheid. Dit kan vooral problematisch zijn met betrekking regels die rechters zelf hebben opgesteld, zoals de oriëntatiepunten voor straftoemeting of de kantonrechtersformule. Ten slotte heeft een sterk socialisatieproces negatieve beeldvorming naar buiten toe tot gevolg. Voor de meesten blijft de rechterlijke macht een enigszins wereldvreemd bolwerk van grijzende, D66-stemmende, blanke mannen, zetelend in een ivoren toren. De gedachte aan een elite met eeuwenoude rituelen, die alleen wordt aangevuld met een groepje uitverkorenen dat een introductietijd en inwijdingrites ondergaat, versterkt bij de buitenwacht dit beeld.

Ik ben geneigd het sterke socialisatieproces binnen de rechterlijke macht als een grotendeels positief verschijnsel te kenschetsen. Naast de al genoemde elementen wil ik in dat verband nog opmerken dat een zekere eenvormigheid en behoudendheid nodig zijn om de gelijkmatigheid en continuïteit van de rechtspraak te waarborgen. Deze gelijkmatigheid en continuïteit zijn noodzakelijk om het rechterlijk oordeel een zweem van tijdloosheid te geven. Met tijdloze rechterlijke oordeelsvorming doel ik niet op een soort ambtsadel (noblesse de robe). Een functionele afstand tot rechtzoekenden is noodzakelijk om de rechter buiten het partijdebat te plaatsen. De in beginsel onbeperkte beoordelingsmacht die het ambt met zich meebrengt, wordt echter onder meer beperkt door het vacuüm waarbinnen rechters oordelen. Dit vacuüm wordt mede in stand gehouden door een sterk socialisatieproces.

In dit verband wil ik verwijzen naar de Amerikaanse rechtsfilosoof Ronald Dworkin, die het recht vergelijkt met een kettingroman die geschreven wordt door opeenvolgende auteurs (Dworkin 1986, p. 228 e.v.). Dworkin richt zich vervolgens vooral tot de rechter. Een rechter die een nieuw hoofdstuk wil toevoegen aan de bestaande jurisprudentie moet eerst de voorafgaande hoofdstukken interpreteren. In overeenstemming met Dworkins integriteitsprincipe zal een rechter een hoofdstuk moeten toevoegen dat een passende, consistente en constructieve aanvulling vormt op de bestaande verhaallijn. Hoewel deze vergelijking het beste aansluit bij een common law-rechtssysteem, waarin precedenten van doorslaggevender belang zijn dan in ons rechtssysteem, is deze vergelijking ook interessant voor de Nederlandse rechter. Door in rechterlijke oordeelsvorming als gedeelde cultuur en geschiedenis eigenschappen te onderkennen van het schrijven van een kettingroman worden juist de hierboven genoemde doelen gelijkmatigheid en continuïteit onderstreept. Door een sterk socialisatieproces leren rechters in opleiding dat zij deel uitmaken van een dergelijke traditie en dat hun manoeuvreerruimte daardoor wordt beperkt.

\section{Rechterlijke oordeelsvorming in de praktijk}

$\mathrm{Nu}$ een beeld is geschetst van de omgeving waarbinnen een rechter in opleiding wordt geleerd een rechterlijk oordeel te vormen, is het van belang aandacht te besteden aan hetgeen dat hem wordt geleerd. Over het onderwerp rechterlijke oordeelsvorming zijn boekenkasten volgeschreven. Het zou het bestek van deze 
bijdrage ver te buiten gaan daarvan een enigszins representatief overzicht te geven. Ik zal daarom proberen enig inzicht te bieden in hoe rechterlijke oordeelsvorming in de praktijk wordt aangeleerd. Om dat inzichtelijk te maken, beschrijf $\mathrm{ik}$ een oplossingsmodel voor civiele zaken dat ik heb aangeleerd tijdens mijn civiele stages. Dit model geeft een handleiding voor de meeste zaken, maar kan logischerwijs niet als spoorboekje voor elke zaak dienen. Ik kies voor een dergelijk model, omdat de ervaring leert dat rechterlijke oordeelsvorming in het civiele vonnis het beste tot uitdrukking komt. In het strafrecht is de rechter gebonden aan het beslissingsmodel van het Wetboek van Strafvordering en worden bovendien de meeste vonnissen geschreven door secretarissen. In het bestuursrecht dicteert de getrapte wet- en regelgeving de uitspraak en blijft er voor de rechter vaak maar weinig beoordelings- en beslissingsruimte over.

\subsection{Beslissingsmodel civiele zaken}

Bij de analyse van een geschil moet worden vastgesteld wat de te beantwoorden rechtsvragen zijn. Daarvoor is van belang dat het verhaal van het geschil inzichtelijk wordt. Bij bestudering van het dossier zullen de aanwezige stukken dus moeten worden doorgelezen op zoek naar een verhaallijn, waarbij een eerste selectie plaatsvindt van feiten die mogelijkerwijs van belang zijn om enige rechtsvraag te beantwoorden. Na deze eerste lezing blijkt vaak dat partijen gedeeltelijk verschillende verhaallijnen presenteren. Deze verschillen moeten worden geïnventariseerd en de onderdelen waarover geen discussie bestaat moeten als zodanig worden afgezonderd. Meestal kan op dit moment al een grof beeld van het verhaal worden gegeven. Op zitting kunnen eventuele gaten worden opgevuld. Dit verhaal vormt de achtergrond van de beantwoording van de rechtsvragen.

Vervolgens kan een inventarisatie van de rechtsvragen plaatsvinden. Deze vragen volgen vaak genoegzaam uit de feitelijke en juridische stellingen. Deze stellingen vormen op hun beurt weer de grondslagen van de vorderingen en verweren van partijen. Na deze inventarisatie worden de rechtsvragen geordend naar mate van verstrekkendheid. Dit betekent dat formele vragen in beginsel eerder beantwoord moeten worden dan materiële rechtsvragen. Als een geschil echter stukloopt op een later te beantwoorden vraag, dan kan de rechter beslissen een eerder te beantwoorden vraag onbeantwoord te laten of veronderstellenderwijs uit te gaan van een positieve beantwoording daarvan. Dit voorkomt onnodige bewijslevering. De rechter wordt geacht de wet te kennen (ius curia novit). Hij heeft dan ook de taak ambtshalve de rechtsgronden aan te vullen. Een inventarisatie van rechtsvragen beperkt zich dus niet tot de door partijen aangevoerde rechtsvragen. Als een partij voldoende feiten heeft aangevoerd, maar ter onderbouwing van haar vordering of verweer vergeet de (juiste) rechtsregel te noemen, dan moet de rechter haar uit eigen beweging helpen. Ter relativering kan hierbij worden opgemerkt dat sommige rechtsfiguren, zoals verjaring, alleen op verzoek van partijen mogen worden toegepast.

$\mathrm{Na}$ deze inventarisatie moet de rechter vaststellen aan de hand van welk criterium hij de rechtsvragen moet beantwoorden. In het overgrote deel van de gevallen kan dit criterium worden afgeleid uit de wet. Soms zijn deze criteria in de rechtspraak nader gespecificeerd. Slechts in zeer bijzondere gevallen zal de rech- 
ter op zoek moeten gaan naar criteria buiten de wet of rechtspraak. In die gevallen zal vaak worden geprobeerd aansluiting te zoeken bij een redelijke wetsuitleg of de bedoeling van de wetgever, zoals die blijkt uit de parlementaire geschiedenis. Als ook dit allemaal geen soelaas biedt, dan zal de rechter zijn toevlucht moeten zoeken tot algemene rechtsbeginselen. Mijn eigen ervaring leert dat dit soort gevallen zich eigenlijk zelden tot nooit voordoet.

$\mathrm{Na}$ de vaststelling van het criterium moet worden bepaald of aan dit criterium is voldaan. In de loop van de procedure zijn de stellingen van partijen vaak voldoende uitgekristalliseerd. Een van de belangrijkste stappen in de rechterlijke oordeelsvorming is vervolgens het vaststellen van een stelplicht en een daaraan gekoppelde bewijslast, en dus bewijsrisico, voor een van de partijen. De steldrempel beslecht een groot deel van de geschillen, waardoor de rechter niet eens toekomt aan beantwoording van de rechtsvragen. Als echter voldoende is gesteld, mede in het licht van een eventuele betwisting door de wederpartij, dan zal moeten worden beoordeeld of de wederpartij voldoende heeft betwist, mede in het licht van de stelling door de eerste partij. Slechts als dit ook het geval is, zal de rechter bewijs opdragen van het feitelijke gedeelte van de stelling.

Nodig voor een rechterlijk oordeel is dus het verhaal, een inventarisatie van de rechtsvragen, een vaststelling van het criterium voor beantwoording van de rechtsvragen, een inventarisatie van de stellingen van partijen per rechtsvraag, een bewijslastverdeling en een bewijsbeslissing. Hierna kan bewijslevering volgen door een partij en bewijswaardering door de rechter.

\subsection{Relativiteit oordeelsvorming}

Voor een goed begrip van rechterlijke oordeelsvorming is noodzakelijk dat wordt onderkend dat bewijslevering betrekking heeft op stellingen van partijen en niet op feiten als zodanig. In het civiele proces is dan ook geen sprake van waarheidsvinding in zuivere zin. Partijen presenteren aan de rechter hun eigen verhaal van een geschil. In de context van dit verhaal nemen zij stellingen in. De bewijsbeslissing van de rechter heeft betrekking op die stellingen en dus op een gepresenteerde werkelijkheid. Hetzelfde geldt voor de vastgestelde feiten in het begin van het vonnis. Hiermee verliezen feiten in een procedure hun zuiverheid, die ze als fenomeen in de werkelijkheid hebben. Bovendien herformuleert de rechter deze stellingen tot rechtsvragen, waarbij hij ze aanpast aan de in zijn ogen relevante rechtsregels. Ook rechtsregels verliezen hierdoor in een procedure hun zuiverheid, die ze als algemeen geldende regel in abstracto hebben.

De partijen en de rechter construeren aldus binnen een procedure een afgebakende werkelijkheid, waarin wordt geoordeeld aan de hand van interne bewijsregels. In de tijd van de vierschaar werd deze afbakening nog fysiek aangebracht door het neerzetten van vier banken (scare of schaere). Hieraan zouden wij het huidige begrip 'rechtbank' te danken hebben (Hol 2006, p. 809). Ook in het huidige tijdsgewricht zijn fysieke en symbolische verwijzingen te vinden naar de afbakening binnen de rechtspraak. Rechterlijke oordelen hebben natuurlijk wel gevolgen buiten deze afgebakende werkelijkheid. Ze zijn echter noodzakelijkerwijs relatief en kunnen eigenlijk alleen goed worden begrepen binnen het rechtssysteem. Uiteraard moet een rechter bij de feitenvaststelling proberen zo veel als 
het rechtssysteem hem toelaat aan te sluiten bij datgene wat de buitenwereld als dé waarheid beschouwt. In een recent verschenen proefschrift van de Nederlandse rechter Ruth de Bock wordt dit streven naar een rechterlijke interpretatie die het meest in overeenstemming is met de werkelijke gang van zaken gepresenteerd als waarheidsvinding (De Bock 2011). Ik leg juist de nadruk op de relativiteit van rechterlijke oordeelsvorming. Verschillende procedureregels, zoals de rechterlijke lijdelijkheid, de beperkte waarde van partijverklaringen en de gevolgen van bewijslastverdeling, versterken deze relativiteit. Hetzelfde geldt voor praktische problemen, zoals een beperkte tijd per zaak, de druk vanuit de organisatie om producten af te leveren en de moeilijkheid om bepaalde bewijsmiddelen op hun juiste waarde te schatten. Dit maakt elk rechterlijk oordeel naar zijn aard arbitrair, wat niet per definitie wil zeggen willekeurig of subjectief. Bovengenoemde procedureregels en praktische beperkingen zorgen namelijk ook voor een voorspelbare begrenzing van de geschilbeslechting. Zo lang sprake is van een behoorlijke procedurele rechtvaardigheid en een redelijke autoriteit van de rechtspraak, zullen rechtzoekenden - zelfs de verliezende partij - het rechterlijk oordeel in de regel als gezaghebbend accepteren. Slechts zelden zullen partijen hun geschil na een definitieve rechterlijke uitspraak met andere middelen voortzetten. Een rechter in opleiding leert daarom vooral om binnen het rechtssysteem aanvaardbare beslissingen te nemen. Datzelfde systeem, maar ook de context van de praktische uitoefening van zijn ambt, legt de rechter in opleiding vervolgens allerlei beperkingen op. Het belangrijkste inzicht is dat de rechter zijn oordeel noodgedwongen relateert aan informatie van partijen. De beoordelingscriteria en procedureregels zijn weliswaar afkomstig uit het recht, maar krijgen slechts toepassing en dus relevantie in het licht van de (vast)gestelde feiten. Toch blijft het de vraag wat er nu gebeurt op het moment dat een criterium wordt getoetst; het moment dat de Nederlandse rechtstheoreticus en rechter-plaatsvervanger Paul Scholten omschrijft als een sprong.

Vaak wijzen ook tijdens dit toetsmoment bewijsregels de weg. Sommige bewijsmiddelen wegen bijvoorbeeld zwaarder dan andere. Bij onduidelijkheid over de oorzaak van een omstandigheid zal in beginsel de partij op wie de bewijslast rust daarvan het risico dragen. In andere gevallen is bewijswaardering vaak een kwestie van gezond verstand. Overtuigend getuigenbewijs is bijvoorbeeld afkomstig van iemand die geen belang heeft bij de uitkomst van het geschil, die consistent verklaart en die zelf niet al te lang geleden heeft waargenomen waarover hij verklaart. Voor de waardering van deskundigenbewijs zijn vergelijkbare toetsingscriteria op te sommen.

Niet alle rechtsvragen vallen echter aan de hand van bewijswaardering te beantwoorden. Bijvoorbeeld de vraag of een beroep op een beding naar maatstaven van redelijkheid en billijkheid onaanvaardbaar is. Een partij kan deze stelling namelijk wel motiveren (toelichten), maar niet onderbouwen (met bewijs schragen). Nadat een rechter alle relevante informatie van partijen heeft verzameld en de relevante rechtsregels heeft bestudeerd, komt er een moment dat hij de knoop moet doorhakken. Dit is echter geen sprong in het duister, een ingeving of een moment van inspiratie. Of in de woorden van Posner (2008, p. 7): 'judges are not moral or intellectual giants (alas), prophets, oracles, mouthpieces, or calculating machines. 
They are all-too-human workers, responding as other workers do to the conditions of the labor market in which they work'. Maar wat is het dan wel?

\subsection{Het bijzondere karakter van rechterlijke oordeelsvorming}

De rechter doordenkt mogelijke oplossingsrichtingen en weegt de uitkomsten daarvan. Uiteindelijk zoekt hij naar beantwoording van de vraag die het meest aansluit bij de gangbare beantwoording van vergelijkbare vragen in het recht. Doordat de rechter in opleiding ingekapseld is geraakt in de rechterlijke macht met haar eigen denkwijze en normen, zal deze beantwoording vaak overeenstemmen met zijn eigen rechtsgevoel. Dit betekent niet dat een rechtsvraag op een bepaalde wijze wordt beantwoord alleen omdat dit al jaren zo gebeurt. Rechters zoeken naar een beantwoording van rechtsvragen die het meest in lijn is met de stand van het recht zoals zij dat op dat moment kennen. Daar is niet zo heel veel mysterieus aan. Hetzelfde doen officieren van justitie, advocaten en andere juristen. De lastige zaken zijn die waarin de uitkomst die het meest in overeenstemming is met het recht niet overeenstemt met het eigen rechtsgevoel. In mijn twintig maanden als civiele rechter heb ik twee keer geoordeeld in een dergelijke zaak. Op het totaal maken deze zaken ongeveer twee procent uit. In beide gevallen heb ik geoordeeld in lijn met de stand van het recht zoals ik die had geanalyseerd, en dus in afwijking van mijn rechtsgevoel. Dit probleem ligt overigens eerder op de loer in zaken waarin de rechterlijke toetsingsintensiteit lager is, zoals in bestuursrechtzaken waar alleen marginaal getoetst mag worden, of in zaken waarin de rechter sterke persoonlijke overtuigingen heeft. Gelet op het voorgaande is het bijzondere aan rechterlijke oordeelsvorming in mijn ogen dan ook niet de methode, maar de status van de uitkomst daarvan.

\section{Tot slot}

De vraag 'hoe denken rechters?' blijft wat mij betreft een intrigerende vraag. Ik heb namelijk niet de illusie dat ik in deze bijdrage een afdoende antwoord hierop heb kunnen geven. Ik heb mij bovendien noodzakelijkerwijs beperkt tot een deelbeantwoording, waarbij ik de vraag heb opgevat als het startpunt van een beschrijving van de omgeving waarbinnen het rechterlijk oordeel wordt gevormd. Deze beschrijving van de context van rechterlijke oordeelsvorming heb ik gegeven vanuit het perspectief van de rechter in opleiding. Juist door de ogen van de rechter in opleiding kan men zicht krijgen op de omgeving waarin rechters oordelen. Voor mijn gevoel krijgt de invloed van deze omgeving op rechterlijke oordeelsvorming te weinig aandacht in de rechtswetenschap.

$\mathrm{Na}$ een schets van de opleiding en de belangrijke rol van het socialisatieproces daarbinnen, heb ik een model beschreven voor de beoordeling van civiele zaken. Aan de hand van dit model zijn conclusies te trekken over de aard van rechterlijke oordeelsvorming. Ik leg hierbij de nadruk op de relativiteit en systeemgebondenheid van rechterlijke oordeelsvorming, zonder dat daarmee sprake is van subjectieve of willekeurige oordeelsvorming. 
Ik kom tot de conclusie dat niet zozeer de methode van rechterlijke oordeelsvorming bijzonder is, maar de status van de uitkomst daarvan. De rechter is weliswaar geen dworkiniaanse Hercules. Aan hem wordt echter wel grote beoordelingsmacht toegekend. Procedurele waarborgen alleen zijn onvoldoende om deze macht volledig te beteugelen. De rechter weet zich echter ingekapseld in zijn beroepsgroep, waarin hij werkt binnen een cultuur met een gedeelde geschiedenis. Zijn oordeel zal daardoor in belangrijke mate aan gelijkmatigheid en continuïteit winnen. Gelet hierop is het mijn stellige overtuiging dat je rechterlijke oordeelsvorming zonder de context daarvan niet volledig kunt begrijpen.

Op dit moment wordt de opleiding tot rechter grondig gereviseerd. In dat licht is het aanbevelenswaardig dat tijdens de opleiding meer uitdrukkelijk zal worden gereflecteerd op rechterlijke oordeelsvorming. Hierbij zal uiteraard aandacht moeten zijn voor de overtuigingen, beweegredenen en vooroordelen van de rechter en de technisch-analytische kant van rechterlijke oordeelsvorming, maar evenzogoed voor de omgeving waarbinnen rechterlijke oordelen worden gevormd en de invloed daarvan op deze oordelen.

\section{Literatuur}

\section{De Bock 2011}

R.H. de Bock, Tussen waarheid en onzekerheid. Over het vaststellen van feiten in de civiele procedure (diss. UvT), Deventer: Kluwer 2011.

\section{Dworkin 1986}

R.M. Dworkin, Law's Empire, Cambridge, MA: Harvard University Press 1986.

\section{Hol 2006}

A.M. Hol, 'Rituelen en symbolen in de rechtspraak. Hun functie en betekenis', Ars Aequi 2006-11.

Holmes Jr. 1897

O.W. Holmes Jr., 'The Path of the Law', 10 Harvard Law Review 457.

\section{Jensma 2007}

F. Jensma, 'Ik blijf een heer', NRC Handelsblad 15 december 2007.

\section{Köhne-Hoegen 2006}

E. Köhne-Hoegen, 'Over de socialisatie en (her)opvoeding van de raio', TREMA 2006-5.

\section{Köhne-Hoegen 2008}

E. Köhne-Hoegen, 'De raio-opleiding als socialisatieproces: uittreders aan het woord', Recht der Werkelijkheid 2008-1, p. 11-34.

\section{Posner 2008}

R.A. Posner, How Judges Think, Cambridge: Harvard University Press 2008.

\section{Rozemond 2011}

K. Rozemond, 'Thinking Like a Lawyer', ReM 2011-1, p. 112-116.

\section{Taekema \& Van Klink 2011}

S. Taekema \& B. van Klink, 'Een nieuwe impuls aan het methodendebat', ReM 2011-1, p. 3-10. 